\title{
A Socio-Legal Study on Tourists' Perception and Opinion towards Immigrant Influx at the Heritage Zone of Kuala Lumpur
}

\author{
Siti Sarah Sulaiman¹, Nur Ezan Rahmat' ${ }^{1}$, Norazlina Abdul Aziz', Saiful Azmi Samad² \\ 1 Faculty of Law, Universiti Teknologi MARA, Shah Alam, Selangor, Malaysia \\ ${ }^{2}$ Selayang Local Council, Selayang Selangor, Malaysia
}

siti_sarah@uitm.edu.my, nurezan@uitm.edu.my, noraz397@uitm.edu.my, saifulazmi.samad@mps.gov.my

Tel: $+6019-3951878$

\begin{abstract}
Kuala Lumpur is one of the tourism destinations which offers a balance of historical and modern development. It has become a central meeting place for the immigrants who monopolised the business operation. This study examines and analyses the perception and opinion of tourists visiting Kuala Lumpur towards the immigrants' influx in the heritage zone. The variables are categorised into three; demographic characteristics of the tourists; tourists' perception and opinion towards the immigrant influx; and tourists' perception and opinion towards heritage conservation and value. The finding helps the stakeholders to formulate a policy in controlling the immigrant influx in Kuala Lumpur.
\end{abstract}

Keywords: tourists; immigrants; heritage zone.

eISSN: 2398-4287@ 2020. The Authors. Published for AMER ABRA CE-Bs by e-International Publishing House, Ltd., UK. This is an open access article under the CC BYNC-ND license (http://creativecommons. org/licenses/by-nc-nd/4.0). Peer-review under responsibility of AMER (Association of Malaysian Environment-Behaviour Researchers), ABRA (Association of Behavioural Researchers on Asians) and cE-Bs (Centre for Environment-Behaviour Studies), Faculty of Architecture, Planning \& Surveying, Universiti Teknologi MARA, Malaysia.

DOI: https://doi.org/10.21834/ebpj.v5i15.2513

\subsection{Introduction}

Tourism is one of the income generations in Malaysia. Places of attraction are diversified; from beautiful island and panoramic hills area to the modern yet historic city centre. The government has invested a lot of money in promoting tourism, not only to local citizens but of course throughout the world. Kuala Lumpur, as the capital state of Malaysia, is a place of attraction where people visiting Malaysia will surely go. It is caused by, among others; its heritage value has not been suppressed by urbanisation. However, as much as we would love to maintain the historical value of Kuala Lumpur, we can see that in a certain area of Kuala Lumpur, immigrants are taking monopoly by running their businesses. This kind of monopoly may bring adverse effects since local people and tourists may have their perspective on visiting a place full of immigrants.

\subsection{Literature Review}

It is undeniable that the main factor that leads to migration is for immigrants to seek better employment. The immigrants are seeking to improve the standard of living while the employers are seeking for the skilled or cheaper workforce. Thus, prohibiting the entry and involvement of immigrants in the economic sector of a country may not be a wise decision. Nathanson (2017) observed that many industries would be understaffed if foreign workers are not employed. However, issues related to immigrants are not novel (Beutin et al., 2007). According to Corrie (2008), immigrants are assets to the communities in which they live. As an asset, Corrie (2008) opines that the immigrants contribute to the various avenues through which they add wealth to society. For example, they are involved in

eISSN: 2398-4287@ 2020. The Authors. Published for AMER ABRA cE-Bs by e-International Publishing House, Ltd., UK. This is an open access article under the CC BYNC-ND license (http://creativecommons.org/licenses/by-nc-nd/4.0/). Peer-review under responsibility of AMER (Association of Malaysian Environment-Behaviour Researchers), ABRA (Association of Behavioural Researchers on Asians) and cE-Bs (Centre for Environment-Behaviour Studies), Faculty of Architecture, Planning \& Surveying, Universiti Teknologi MARA, Malaysia.

DOI: https://doi.org/10.21834/ebpj.v5i15.2513. 
purchasing goods and services in the communities in which they live. In small and large communities, immigrants' buying power can be an important engine for economic growth. Another example could be found in the fact that immigrants serve as an important supply of labour to the local workforce. This is the positive impact of having immigrants as players in the economic sector.

However, looking at another perspective, which is the main focus of this study, which explains the perception and opinions of tourists towards the existence of immigrants in Kuala Lumpur. The first question to be answered here is what are the factors which have influenced the tourists to come to Malaysia, particularly Kuala Lumpur. Syakir Amir et al. (2014) mention that the decision-making process is influenced by some internal and external variables. Internal variables refer to psychological elements and external variables refer to non-psychological elements. The criteria that always been highlighted by Um and Crompton (1990) and Sirakaya and Woodside (2005) includes personal (push) factors and destination attributes (pull factors). Among others, Syakir Amir et al. (2014) and Yerik Afrianto Singgalan et al. (2019) believe that among the consideration are prices and distance, climate as well as quality and pricing.

Residents of a nation or region are likely to have negative attitudes toward immigrants, including concerns about criminal activity that may threaten the safety and lifestyle security (Simpson et al. (2016)). Simpson et al. (2016) also mention that attitudes toward undocumented immigrants are also likely to affect travellers' perceived safety in the destination, likelihood of recommending the area to others and return intention to that area. Moufakkir (2014) proposed that animosity towards immigrants affects intention to visit the country of origin of the said group (the immigrants) for tourism purposes. Shafaqat Mehmood, Zahid Ahmad, \& Ather Azim Khan (2016) believed that when immigrants are not able to obtain economic success by legitimate means, they often participate in illegitimate activities. In many cases, the legitimate work of an immigrant may not be enough to sustain them, which can lead to participation in illegitimate work. Immigrants may increase crime rate by displacing local people within the job market. If many immigrants receive jobs in a specific area, this may cause loss of jobs to local people, and then they can commit a deviant act to sustain themselves.

On the other hand, Balli et al. (2016) studied the nexus between immigrant- tourism in different perspective whereby they concluded that tourists would visit immigrants' home countries with higher standards of institutional quality, civil liberty and freedom. Again, the issue centralises on the aspect of security since the study showed that tourists prefer to go to a country which emphasised stability and peaceful environment. In addition to that, Sulaiman et al. (2020) conducted a legal study by discussing the application of planning law in regulating immigrants' activities in Kuala Lumpur as part of the heritage-tourism destination. The immigrants' activities shaped the environmental setting, which reflects the perception and opinion of tourists visiting a particular country.

According to Berry and Hau (2016), when immigrants remain attached to their heritage culture and also become involved in their new society, they achieve a greater level of wellbeing. In sharp contrast, when they are disengaged from both cultures, lacking bonding and bridging capital, they have poorer outcomes. This will determine how long would the immigrants stay in one place. If the immigrants feel comfortable living and surviving in one area, it will be unlikely for them to leave that place. Therefore, the government must emphasise on this matter in regulating immigrant's activities, especially in Kuala Lumpur. Moufakkir (2014) states that tourism can be used as a political tool in so many ways, including policy-making and planning, sustainable development, travel restrictions, empowerment and development, destination marketing and public relations, and political and ideological reasons. As suggested by Simpson et. al (2016) and Milan et. al (2016), security is the main issue which the tourists will consider before embarking into a vacation at any places full of immigrants. Hence, to maintain the flow of tourists, the government should formulate and reinforce security measures as it will give confidence towards the tourists.

A similar study was conducted in Greece where primary qualitative research with the use of semi-structured interviews has been conducted between October 2016 and March 2017. The sample of the research was selected by random sampling, and it involved 122 participants who were separated in two groups: a) representatives of state bodies and local authorities as well as local entrepreneurs and b) independent volunteers and members of Non-Governmental Organizations (NGO). The main findings of the primary research showed a negative attitude of the local stakeholders as to the effects of the refugees' inflows on the economic and social life of both islands and, therefore, on tourism. (Paris Tsartas et al., 2019)

\subsection{Research Methodology}

This research has adopted a mixed method which is a combination of qualitative and quantitative methods. For the qualitative method, primary and secondary data were collected and analysed in obtaining an in-depth understanding of this issue (Nuraisyah Chua Abdullah, 2018). The primary data of this research was obtained through semi-structured interviews with relevant officers from various departments at the Kuala Lumpur City Hall. The secondary data was obtained from the statutes, books, journals and online articles. Apart from that, participant observation was also useful for this research. It allows researchers to observe events that respondents may be unable or unwilling to share. In this situation, the businesses and social activities of the immigrants in the heritage zone of Kuala Lumpur were observed and some photos have been taken for evidence purpose.

For quantitative method, this tradition is strong in the field, which involves the impact of the law on society. (G.R. Mullane,1998, S. Mechoulan, 2006) This research adopted a descriptive method. Descriptive research is a type of quantitative research that involves making careful descriptions of a phenomenon. (Parmjit Singh, Chan Yuen Fook, \& Gurnam Kaur Sidhu, 2006). The researchers are interested in getting the thoughts, perceptions and opinions of a population relating to the issue in question. It is to find out how the members of the population distribute themselves in the variables. The combination of methods involves the collection, analysis, and integration of qualitative and quantitative data in this study. (Sharlene Nagy Hesse-Biber, 2010) The researchers have used the qualitative study to generate a specific set of theories and then tested out these generated ideas on a more representative population (QUAL - Quan). (Sharlene Nagy Hesse-Biber, 2010) 
For data collection, questionnaires have been distributed to 50 tourists in some areas of Kuala Lumpur. This sample from the tourists' population has been identified by using convenience sampling. According to (Uma Sekaran and Roger Bougie, 2009), this sampling involves whoever happens to be available in a particular setting and the elements involved do not have a known or predetermined chance of being selected as subjects. The questionnaire consists of three parts, namely demographic characteristics, perception and opinion of tourists on the immigrant influx in the heritage zone of Kuala Lumpur and perception and opinion of tourists towards heritage conservation and value. Likert scale is used in the second and third parts to measure the strength of an attitude or an opinion. It consists of questions which are simple, direct and easy to understand.

\subsection{Discussion and Analysis}

\subsection{The Laws and Policies Related to the Immigrants in Kuala Lumpur}

The local planning authority has the power to control and regulate all development activities conducted in the Kuala Lumpur City Centre. All developments have to follow the strict guidelines imposed by the local authority. As Kuala Lumpur has an outstanding national heritage significance, its historic buildings need to be protected and preserved. In conserving heritage buildings, Kuala Lumpur City Hall has established Heritage Zone in order to ensure that buildings located in this zone will maintain their historical character or ambience as prescribed in the Kuala Lumpur Urban Design Guidelines (UDG). Heritage zones are classified into the primary zone, secondary zone, special character zone and heritage site.

The local authority seriously controlled on the cleanliness and enforcement of advertisement boards. Concerning this, criticisms were made against Kuala Lumpur City Hall due to their failure in monitoring and enforcing the law on the immigrants. This is when all the advertisement boards are using Nepalese and Bangladeshi words. Thus, the character of the area has changed to become an alien place to the Malaysian citizens. Spitting and littering are also aspects that the authority needs to control. Based on the observation, the aspect of cleanliness and advertisement board are under control. The Prohibition against Spitting (Federal Territory of Kuala Lumpur) By-Laws 2017 was passed on 15 March 2017 to give power to the local authority to penalise anyone who spits in the area.

In achieving the high-income nation status in 2020, Malaysia depends upon labourers in various sectors. In relations to this, immigrant workers would be able to solve the issue of lack of human resources. Some employees prefer immigrant workers over local workers because the salary paid to immigrants is cheaper. The issue becomes worse when the local workers demand higher salary due to the increase in the living cost. Employees have the right to choose the cheapest human resources. The policy on hiring foreign workers is decided at the federal government level. It was decided among others that, foreign workers should come from the approved source countries and under the specific sector. Foreign workers will only be allowed to enter Malaysia at the authorised entry points using visa with reference issued by the Immigration Department and entry visa issued by the Malaysian Attachés Office in the country of origin. The employers must ensure that the clearance process of foreign workers at the entry points is done within 24 hours of the arrival time. The issuance of Visit Pass (Temporary Employment) [VP(TE)] to the foreign workers will only be done after they have passed the medical examination within 30 days which can be done at any medical centres registered. VP (TE) will be issued once the foreign worker is certified fit by the medical centre. Failing which, the foreign worker will not be allowed to stay and work in Malaysia. According to section 6(3) of the Immigration Act 1959/63 (Act 155), living and staying in Malaysia without a valid pass or permit is an offence.

The business operated by the immigrants includes every form of trade, commerce, craftsmanship, calling, profession or other activities carried on for gain, but does not include any office or employment or any charitable undertaking or any occupation specified in the Schedule of the Registration of Businesses Act 1956 (ROBA 1956) \& ROBA Rules 1957. The business that may be registered under the ROBA 1956 is a business operated in West Malaysia which includes Peninsular Malaysia and the Federal Territory. The types of business are sole proprietorship and partnership. A business may be registered using personal name or a trade name. The business name using a personal name as stated in the identity card is not required to apply for business name. The applicant is required to complete the Business Registration Form (Form A) with a list of information namely business name, commencement date of business, principal place of business, the address of the branch of business (if any), information of owner and partners, type of business carried out and a copy of the Partnership Agreement (if any). Every business owner and partner must sign the completed form and be present at the counter for registration. The applicant should also be notified that although businesses have been registered with Companies Commission of Malaysia (SSM), business owners are responsible for obtaining licences, permits or approval letters from other relevant authorities in order to operate their businesses. In most cases, the owner of the premises and businesses are Malaysians but rent them out to the immigrants. In some situations, the immigrants claim that they are working for the shop owners who are Malaysians. Therefore, the enforcement officer has no case against the immigrants as they are able to provide valid permits and licences and the businesses operated are in line with the law.

\subsection{Quantitative Data Analysis}

The questionnaires have been distributed to 50 respondents who were tourists in some areas of Kuala Lumpur before the pandemic of covid19 affects the tourism industry.

\section{Part A: Demographic Characteristics}


Majority of the respondents involved in this survey were between 20-39 years old who can be categorised as young and energetic. They represent $70 \%$ of the whole sample. $72 \%$ are males while the balance of $28 \%$ are females. Tourists from Asia dominating the number which is $65 \%$ while the rest were from Europe, the United States of America, Africa and Oceania.

\section{Part B: Perception and Opinion on Immigrant Influx}

The Likert Scale has been used in this part. The scales are between Strongly Disagree, Disagree, Neutral, Agree and Strongly Agree. The questions from this part are:

Influx1- The immigrant influx affects the cleanliness of Kuala Lumpur.

Influx2- The business of local people has been interfered by the immigrants.

Influx3- Immigrant activities have changed the social characteristics of the city.

Influx4- Health issue is a problem since some of the immigrants brought along diseases with them.

Influx5- Tourists will feel insecure when visiting places crowded with immigrants.

Table 1: Mean on Perception and Opinion on Immigrant Influx

\begin{tabular}{|c|c|c|c|c|c|c|c|c|}
\hline & $\begin{array}{l}\mathrm{N} \\
\text { Statistic }\end{array}$ & $\begin{array}{l}\text { Range } \\
\text { Statistic }\end{array}$ & $\begin{array}{l}\text { Minimum } \\
\text { Statistic }\end{array}$ & $\begin{array}{l}\text { Maximum } \\
\text { Statistic }\end{array}$ & $\begin{array}{l}\text { Mean } \\
\text { Statistic }\end{array}$ & Std. Error & $\begin{array}{l}\text { Std. Deviation } \\
\text { Statistic }\end{array}$ & $\begin{array}{l}\text { Variance } \\
\text { Statistic }\end{array}$ \\
\hline Influx1 & 50 & 4 & 1 & 5 & 3.50 & .138 & .974 & .949 \\
\hline Influx2 & 50 & 4 & 1 & 5 & 3.48 & .129 & .909 & .826 \\
\hline Influx3 & 50 & 4 & 1 & 5 & 3.80 & .140 & .990 & .980 \\
\hline Influx4 & 50 & 4 & 1 & 5 & 3.44 & .146 & 1.033 & 1.068 \\
\hline Influx5 & 50 & 4 & 1 & 5 & 3.36 & .124 & .875 & .766 \\
\hline \multicolumn{9}{|c|}{ Valid N (listwise) 50} \\
\hline
\end{tabular}

The mean for Influx1, Influx2, Influx3, Influx4 and Influx5 are between 3.44 to 3.80 which means the response is between Neutral and Agree.

\section{Part C: Perception and Opinion Towards Heritage Conservation and Value}

The Likert Scale has been used in this part. The scales are between Strongly Disagree, Disagree, Neutral, Agree and Strongly Agree. The questions from this part are:

Heritage1: Buildings in Kuala Lumpur fulfil the criteria of heritage buildings.

Heritage2: The uniqueness of the heritage buildings is one of the reasons why tourists visited Malaysia.

Heritage3: The heritage buildings in Kuala Lumpur are well preserved by the government.

Heritage4: The influx of immigrants affected heritage value.

Heritage5: New development in Kuala Lumpur affects the heritage conservation and value of the buildings.

Table 2: Mean on Perception and Opinion Towards Heritage Conservation and Value

\begin{tabular}{lllllllll}
\hline & $\mathrm{N}$ & Range & Minimum & Maximum & Mean & Std. Deviation & Variance \\
& Statistic & Statistic & Statistic & Statistic & Statistic & Std. Error & Statistic & Statistic \\
\hline Heritage1 & 50 & 4 & 1 & 5 & 3.58 & .111 & .785 & .616 \\
Heritage2 & 50 & 3 & 1 & 4 & 3.26 & .156 & 1.103 & 1.217 \\
Heritage3 & 50 & 2 & 2 & 4 & 3.64 & .074 & .525 & .276 \\
Heritage4 & 50 & 4 & 1 & 5 & 3.22 & .132 & .932 & .869 \\
Heritage5 & 50 & 3 & 2 & 5 & 3.70 & .087 & .614 & .378 \\
Valid N (listwise) & 50 & & & & & & & \\
\hline
\end{tabular}

The mean for Heritage1, Heritage2, Heritage3, Heritage4 and Heritage 5 are between 3.22 to 3.70 , which means the response is between Neutral and Agree.

\section{The T-Test (Independent Samples Test)}

Table 3: Independent Samples Test for Perception and Opinion on Immigrant Influx Between Male and Female Tourists

\begin{tabular}{|c|c|c|c|}
\hline & & Levene & \\
\hline & & $\mathrm{F}$ & Sig. \\
\hline Influx1 & $\begin{array}{l}\text { Equal variances assumed } \\
\text { Equal variances not assumed }\end{array}$ & $\begin{array}{l}.187 \\
\end{array}$ & .668 \\
\hline Influx2 & $\begin{array}{l}\text { Equal variances assumed } \\
\text { Equal variances not assumed }\end{array}$ & .105 & .748 \\
\hline Influx3 & $\begin{array}{l}\text { Equal variances assumed } \\
\text { Equal variances not assumed }\end{array}$ & 2.855 & .098 \\
\hline Influx4 & $\begin{array}{l}\text { Equal variances assumed } \\
\text { Equal variances not assumed }\end{array}$ & .009 & .925 \\
\hline Influx5 & $\begin{array}{l}\text { Equal variances assumed } \\
\text { Equal variances not assumed }\end{array}$ & 2.280 & .138 \\
\hline
\end{tabular}


The above table shows the Levene's Tests of Equality of Variances. $p=$ less than .05

Influx1, Influx2, Influx3 and Influx 5 are $0.187,0.105,2.855$ and 2.280 respectively. These numbers show that there is no significant difference between the perception and opinion of male and female tourists towards the immigrant influx. Influx4, which is 0.009 has a significant difference.

Table 4: Independent Samples Test for Perception and Opinion Towards Heritage Conservation and Value Between Male and Female Tourists

\begin{tabular}{clcc}
\hline & & \multicolumn{2}{c}{ Levene's Test for Equality of Variances } \\
Sig.
\end{tabular}

For perception and opinion of male and female tourists towards heritage conservation and value, the $F$ value for all points is more than 0.05. Therefore, there is no significant difference between the two, male and female tourists. Both genders have similar perception and opinion towards the immigrant influx in Kuala Lumpur.

\subsection{Conclusion and Recommendations}

In conclusion, most of the tourists visiting Kuala Lumpur are in the opinion that the immigrant influx affects the cleanliness, interferes the business of local people, changes the social characteristics of the city and increases health problem. The tourists also feel insecure when visiting places surrounded by immigrants. The issue of immigrants dominating business activities in Kuala Lumpur has changed the character and ambience of the area. These changes may affect the perception of tourists, thus give impact to the inclination of tourists to visit Kuala Lumpur. Immediate action must be taken by the Malaysian government to issue a policy that all streets in the City Centre should be free from premises operated by the immigrants. Not only that, the types of business conducted must reflect Malaysian concept. Kuala Lumpur City Council should leverage the Local Plan to guide all decision made towards rebranding heritage trail in Kuala Lumpur. The entrance and reliance towards foreign workers should be minimised. When the number of immigrants in Kuala Lumpur City Centre is declining, it is easy for the local authority to regulate the area. Since the uniqueness of the heritage buildings in Kuala Lumpur is one of the reasons for the tourists to come to Malaysia, it is suggested that the government should invest more towards heritage conservation and value of the buildings. As this research focus on the immigrant influx at heritage zone in Kuala Lumpur, further study can be made to extend the scope of research to cover the World Heritage Site in Melaka and Pulau Pinang.

\section{Acknowledgements}

The authors gratefully acknowledge the financial assistance from the Faculty of Law, Universiti Teknologi MARA. Special thanks to the officers at the Kuala Lumpur City Hall and all respondents who have participated in this research.

\section{Paper Contribution to Related Field of Study}

It is hoped that the finding of the study will help the stakeholders or policymakers to formulate a policy in controlling immigrant influx in Kuala Lumpur.

\section{References}

Avraham, E. (2004). Media strategies for improving an unfavourable city image. DOI:10.1016/j.cities.2004.08.005

Balli, F., Balli, H.O., \& Louis, R.J. (2016). The impacts of immigrants and institutions on bilateral tourism flows. Tourism Management, 52, 221-229.

Berry, J.W., \& Hau, F. (2016). Immigrant Acculturation and Wellbeing in Canada. Canadian Psychology, 57 (4), 254-264.

Beutin, R., Canoy, M., Anna Horvath, A., Hubert, A. (2007). Reassessing the Link between Public Perception and Migration Policy. European Journal of Migration and Law, 9, 389-418

Cherifi, B., Smith, A., Maitland, R., \& Stevenson, N. (2014). Destination images of non-visitors. Annals of Tourism Research. 49, 190-202.

Corrie, B.P. (2008). A New Paradigm for Immigrant Policy: Immigrant Capital. William Mitchell Law Review. 35, 283-308.

G. R. Mullane. (1998). Evidence of Social Science Research: Law, Practice and Options in the Family Court of Australia, Australian Law Journal. $72,434$. 
Milan, O.C., Simpson, J.J., Simpson, P.M., \& Choi, W. (2016). Reassurance or reason for concern: Security forces as a crisis management strategy. Tourism Management, $56,114-125$

Nathanson, J. (2017, March 2). A region without immigrants. The Daily Record. Retrieved from https://www.lexisnexis.com.ezaccess.library.uitm.edu.my/my/academic/Default.asp

Nuraisyah Chua Abdullah. (2018). Legal Research Methodology. Sweet \& Maxwell Malaysia.

Omar Moufakkir. (2014). What's immigration got to do with it? Immigrant animosity and its effects on tourism. Annals of Tourism Research, 49, $108-121$.

Paris Tsartas (et al). (2019). Refugees and Tourism: A Case Study from the Islands of Chios and Lesvos, Greece. Current Issues in Tourism, Vol 23, Issue 11, 1322.

Parmjit Singh, Chan Yuen Fook \& Gurnam Kaur Sidhu. (2006). A Comprehensive Guide to Writing A Research Proposal. Venton Publishing, 111.

S. Mechoulan. (2006). Divorce Laws and the Structure of American Family. Journal of Legal Studies, 35, 143.

Shafaqat Mehmood, Zahid Ahmad, \& Ather Azim Khan. (2016). Dynamic relationships between tourist arrivals, immigrants, and crimes in the United States. Tourism Management, 54, 383-392.

Sharlene Nagy \& Hesse-Biber. (2010). Mixed Methods Research: Merging Theory With Practice, The Guilford Press New York, 3-53.

Simpson, J.J., Simpson, P.M., \& Milan, O.C. (2016). Attitude towards immigrants and security: Effects on destination-loyal tourists. Tourism Management, 57, 373-386.

Sulaiman , S. S. ., Rahmat , N. E. ., \& Azizun , N. . (2020). Legal Issues and Challenges in Managing Kuala Lumpur as a Tourism Destination: A case study of Silang Street. Environment-Behaviour Proceedings Journal, 5(SI1), 205-210. https://doi.org/10.21834/ebpj.v5iSI1.2321

Syakir Amir, Mariana Mohamed Osman, Syahriah Bachok and Mansor Ibrahim (2014). Understanding of Tourists' Preferences Pattern: A Study in Melaka, Malaysia. Planning Malaysia: Urban Planning and Local Governance, III, 81- 94

Sirakaya, E., \& Woodside, A. G. (2005). Building and testing theories of decision making by travellers. Tourism Management, 26, 815-832

Um, S., \& Crompton, J. L. (1990). Attitude determinants in tourism destination choice. Annuals of Tourism Research, 17(3), 432-448

Uma Sekaran \& Roger Bougie. (1992). Research Methods for Business: a Skill Building Approach, U.S.: John Wiley \& Sons, 2, 262-270.

Yerik Afrianto Singgalan, Gatot Sasongko \& Pamerdi Giri Wiloso (2019). Efforts to Achieve Environmental Sustainability through Ecotourism, Journal of Indonesian Tourism and Development Studies, e-ISSN: 2338-1647. 